\title{
15 years journey of idiopathic pulmonary arterial hypertension with BMPR2 mutation
}

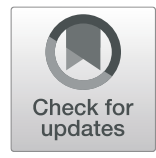

Kyung Jin Ahn ${ }^{1,2}$, Albert Youngwoo Jang ${ }^{1,3}$, Su Jung Park ${ }^{1,3}$ and Wook-Jin Chung ${ }^{1,3^{*}}$ (D)

\begin{abstract}
Pulmonary arterial hypertension (PAH) is known as one of diseases with the worst prognosis. Recently, targeted PAH drugs have been developed and approved for use; therefore, the treatment strategy and goals have changed, and the prognosis has improved over two decades. We reviewed the case of a female who showed the natural disease course of heritable PAH in treatment with the targeted PAH drugs under the Korean Health Insurance policy. At the age of 15, she visited the outpatient clinic for dyspnea on exertion that occurred 3 years ago. At that time, severe pulmonary hypertension was revealed by an echocardiography and there was no evidence of significant shunt lesion or embolism. After 4 years of loss to follow-up, her performance was WHO functional class III and she still suffered from dyspnea. The initial monotherapy using an endothelin receptor antagonist was started in 2008. After 2 years, BMPR 2 mutation was detected. Her clinical symptoms gradually worsened because of poor compliance. To escalate therapy, combination therapy was given, and finally, triple maximal therapy was maintained. The next step is to consider intravenous prostanoids. Various combinations of targeted therapy have been tried, and several trials have been confirmed that improve the prognosis. Initial upfront combination therapy and a more enthusiastic approach make good a better prognosis. In this area, active support of the government insurance policy is indispensable in Korea.
\end{abstract}

Keywords: Pulmonary arterial hypertension, Combination therapy, Bone morphogenetic protein receptors, type II

\section{Letter to the Editor}

Pulmonary arterial hypertension (PAH) is known to be one of diseases with the worst prognosis. Forty years ago, the American national study reported that the estimated median survival of 194 patients who were diagnosed the primary pulmonary hypertension was 2.8 years [1]. However, the advent of targeted PAH drugs have opened a new era [2, 3]. According to evidence based studies [4-9], the drugs have been developed and approved for use, therefore, the treatment strategy and goals have changed to sequential combination therapy and upfront therapy [10-13]. The prognosis has remarkably improved over two decades [14]. The confidential treatment guidelines are proposed according to the individual risk stratification and the precise diagnosis and classification as deep-

\footnotetext{
* Correspondence: heart@gachon.ac.kr

'Gachon Cardiovascular Research Institute, Gachon University, Incheon, Republic of Korea

${ }^{3}$ Department of Cardiovascular Medicine, Gachon University Gil Medical Center, 21 Namdong-daero 774beon-gil, Namdong-gu, Incheon 21565, Republic of Korea

Full list of author information is available at the end of the article
}

phenotyping [15]. However, the guidelines may not be similarly implemented in each country because of each government's insurance policy. We report here on a case of a female who showed the natural disease course of heritable $\mathrm{PAH}$ in treatment with the targeted PAH drugs under the Korean Health Insurance policy. At the age of 15 , she visited the outpatient clinic for dyspnea on exertion that initially occurred 3 years before. At that time, severe pulmonary hypertension was revealed by echocardiography and there was no evidence of significant shunt lesion or embolism. After 4 years of loss to follow-up, her performance was WHO Functional Class III as a more aggravated functional state, and she still suffered from severe PAH related symptoms. The right heart catheterization and work-up for risk stratification were performed. The mean pulmonary arterial pressure detected $83 \mathrm{mmHg}$ and the vaso-reactivity tests under inhaled oxygen and iloprost were all negative, respectively. The calculated pulmonary vascular resistance was 2261.6 dyne.sec. $\mathrm{cm}^{-5}$. The initial monotherapy, using an endothelin receptor antagonist, was started in 2008. After

(c) The Author(s). 2019 Open Access This article is distributed under the terms of the Creative Commons Attribution 4.0 International License (http://creativecommons.org/licenses/by/4.0/), which permits unrestricted use, distribution, and 


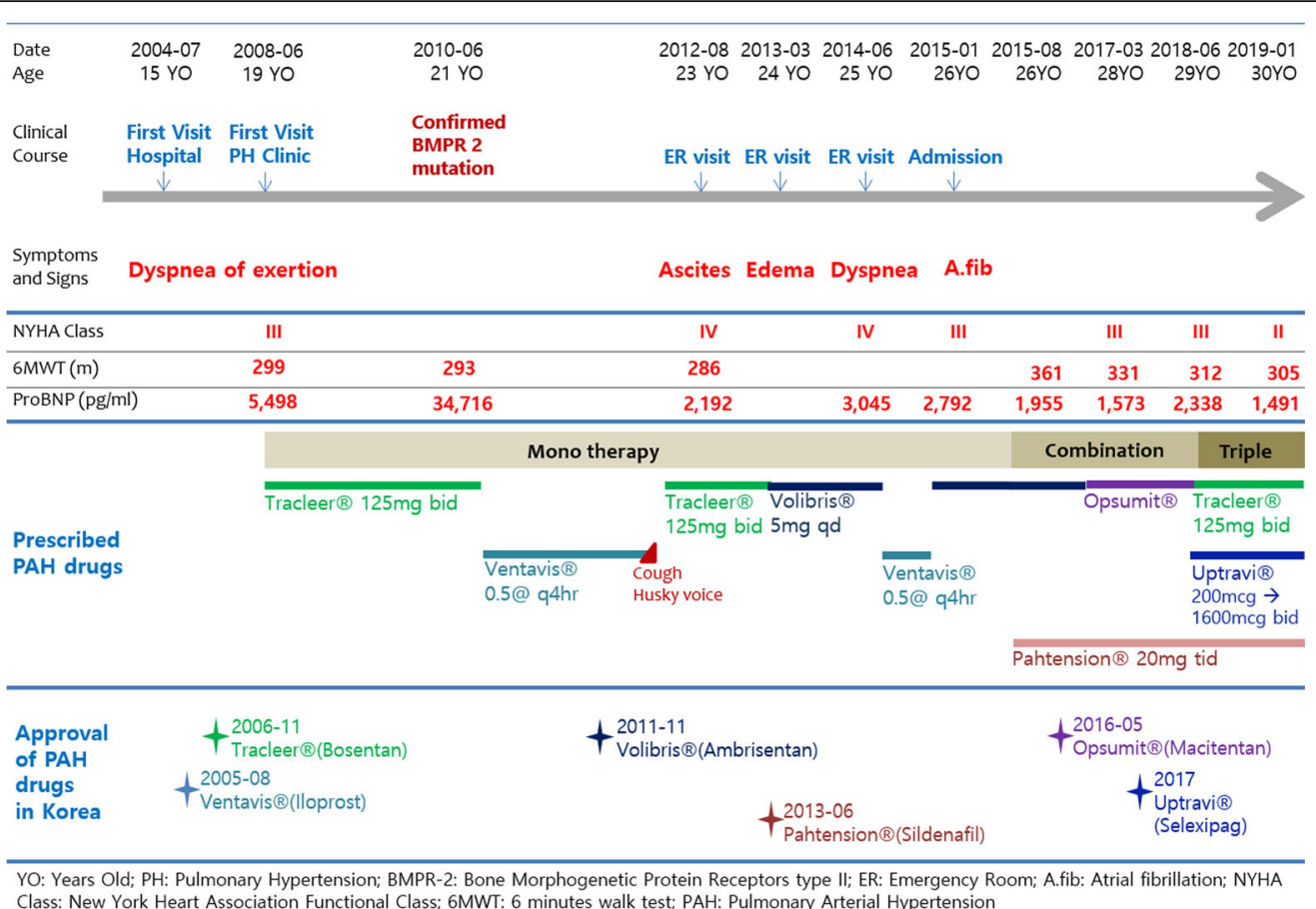

Fig. 1 Chronicle of the patient's clinical features and treatments of PAH specific drugs

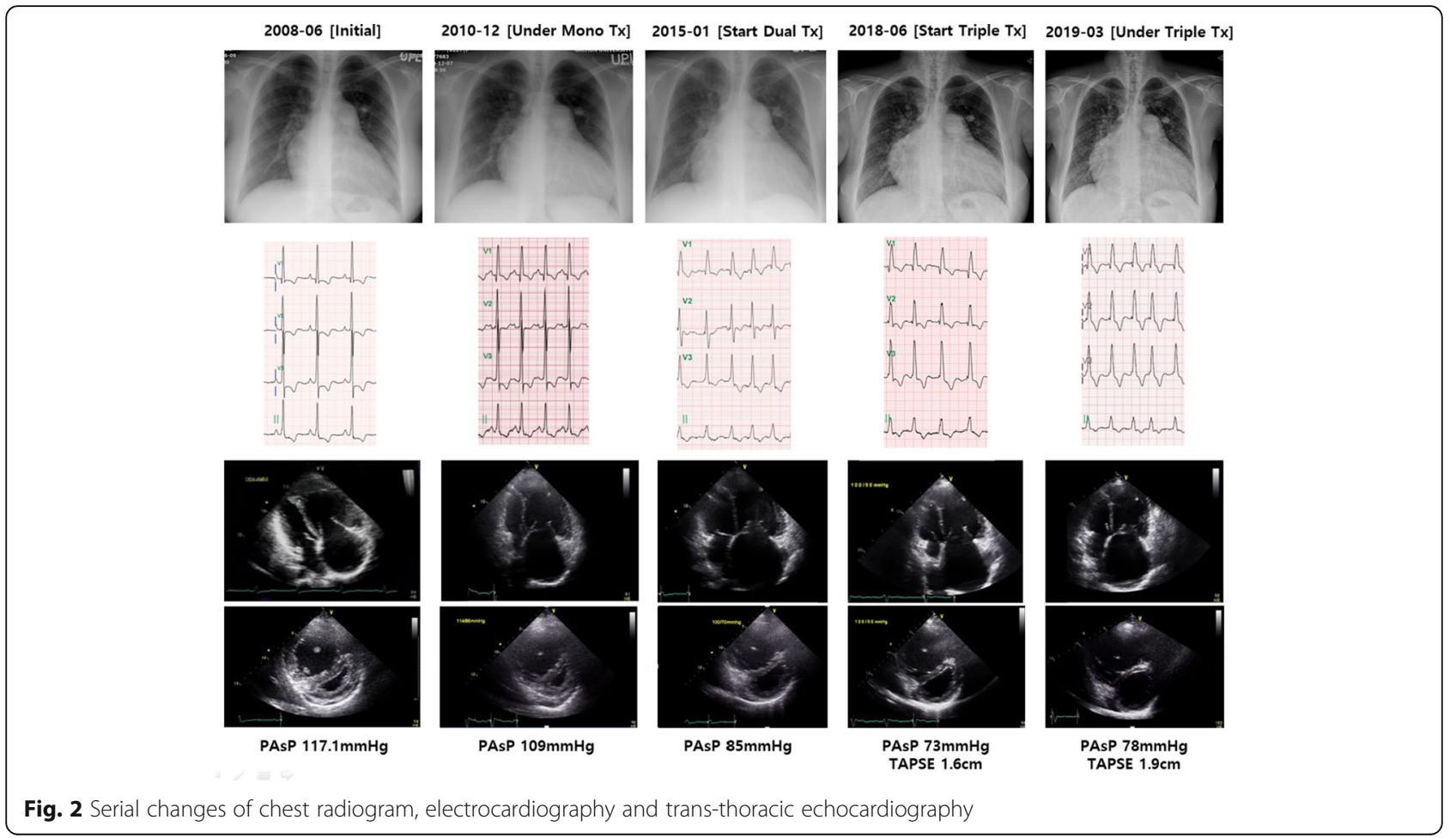


2 years, the bone morphogenetic protein receptors (BMPR) type II mutation was confirmed. She carried exon 6 c.631C > T nonsense mutation. Her clinical symptoms gradually worsened because of poor compliance. There were some minor complications as dry cough and changing her voice, but we maintained medications and encouraged the patient. Even though much effort was given, her clinical symptoms deteriorated. To escalate therapy, combination therapy was given and finally triple maximally therapy was maintained (Fig. 1). The serial chest radiogram, electrocardiogram, and trans-thoracic echocardiography showed improvement after sequential combination therapy was administered (Fig. 2). The next step is to consider intravenous prostanoids. Unfortunately, in Korea, we have no further options. To improve prognosis, diagnosis of early disease detection and aggressive early treatment is needed. Especially, intravenous prostanoids are recommended to high risk patients, and are shown to improve outcomes [16]. For example, Japan has a remarkably good prognosis for PAH [17, 18]. What made this outcome possible is the liberal, applicable, targeted drug usage for variable situations to manage PAH patients. Upfront combination therapy and more enthusiastic approaches improve prognosis [19]. In this area, active support of the government insurance policy is indispensable and the most potent factor for improving prognosis. In conclusion, we can propose a good prognosis by appropriate targeted drugs treating the patients with pulmonary hypertension under the supportive government policy.

\section{Abbreviations}

BMPR 2: Bone morphogenetic protein receptor type 2 gene; PAH: Pulmonary arterial hypertension; WHO: World Health Organization functional class

\section{Acknowledgements}

We thank Mi Ju You, RN. and Gyeong-Lim Hyun, BS. for the support of this manuscript.

\section{Disclosures}

None.

\section{Authors' contributions}

KJA drafted the manuscript. AYJ revised the manuscript. WJC conceived of the case, and participated in coordination and helped to draft the manuscript. All authors read and approved the final manuscript.

\section{Funding}

This research was supported by grants (2018-ER6304-00 and 2018-ER6304-01 by Research of Korea Centers for Disease Control and Prevention).

\section{Availability of data and materials}

Not applicable

\section{Ethics approval and consent to participate}

This case report was complied with the Declaration of Helsinki (6th revision).

\section{Consent for publication}

Written informed consent was obtained from the patient for publication of their individual details and accompanying images in this manuscript. The consent form is held by the authors' institution and is available for review by the Editor-in-Chief.

\section{Competing interests}

The authors declare that they have no competing interests.

\section{Author details}

${ }^{1}$ Gachon Cardiovascular Research Institute, Gachon University, Incheon, Republic of Korea. ${ }^{2}$ Department of Pediatrics, Gachon University Gil Medical Center, Incheon, Republic of Korea. ${ }^{3}$ Department of Cardiovascular Medicine, Gachon University Gil Medical Center, 21 Namdong-daero 774beon-gil, Namdong-gu, Incheon 21565, Republic of Korea.

Received: 22 May 2019 Accepted: 9 August 2019

Published online: 01 October 2019

\section{References}

1. D'Alonzo GE, Barst RJ, Ayres SM, Bergofsky EH, Brundage BH, Detre KM, Fishman AP, Goldring RM, Groves BM, Kernis JT, et al. Survival in patients with primary pulmonary hypertension. Results from a national prospective registry. Ann Intern Med. 1991;115(5):343-9.

2. Park YM, Chung WJ, Choi DY, Baek HJ, Jung SH, Choi IS, Shin EK. Functional class and targeted therapy are related to the survival in patients with pulmonary arterial hypertension. Yonsei Med J. 2014;55(6):1526-32.

3. Chung WJ, Park YB, Jeon CH, Jung JW, Ko KP, Choi SJ, Seo HS, Lee JS, Jung $\mathrm{HO}$, Investigators K. Baseline characteristics of the Korean registry of pulmonary arterial hypertension. J Korean Med Sci. 2015;30(10):1429-38.

4. Barst RJ, Rubin LJ, Long WA, McGoon MD, Rich S, Badesch DB, Groves BM, Tapson VF, Bourge RC, Brundage BH, et al. A comparison of continuous intravenous epoprostenol (prostacyclin) with conventional therapy for primary pulmonary hypertension. N Engl J Med. 1996;334(5):296-301.

5. Simonneau G, Barst RJ, Galie N, Naeije R, Rich S, Bourge RC, Keogh A, Oudiz $R$, Frost A, Blackburn SD, et al. Continuous subcutaneous infusion of treprostinil, a prostacyclin analogue, in patients with pulmonary arterial hypertension: a double-blind, randomized, placebo-controlled trial. Am J Respir Crit Care Med. 2002;165(6):800-4.

6. Olschewski H, Simonneau G, Galie N, Higenbottam T, Naeije R, Rubin LJ, Nikkho S, Speich R, Hoeper MM, Behr J, et al. Inhaled iloprost for severe pulmonary hypertension. N Engl J Med. 2002;347(5):322-9.

7. Barst RJ, McGoon M, McLaughlin V, Tapson V, Rich S, Rubin L, Wasserman K, Oudiz R, Shapiro S, Robbins IM, et al. Beraprost therapy for pulmonary arterial hypertension. J Am Coll Cardiol. 2003;41(12):2119-25.

8. Channick RN, Simonneau G, Sitbon O, Robbins IM, Frost A, Tapson VF, Badesch DB, Roux S, Rainisio M, Bodin F, et al. Effects of the dual endothelin-receptor antagonist bosentan in patients with pulmonary hypertension: a randomised placebo-controlled study. Lancet. 2001; 358(9288):1119-23.

9. Rubin LJ, Badesch DB, Barst RJ, Galie N, Black CM, Keogh A, Pulido T, Frost A, Roux S, Leconte I, et al. Bosentan therapy for pulmonary arterial hypertension. N Engl J Med. 2002;346(12):896-903.

10. Humbert M, Barst RJ, Robbins IM, Channick RN, Galie N, Boonstra A, Rubin LJ, Horn EM, Manes A, Simonneau G. Combination of bosentan with epoprostenol in pulmonary arterial hypertension: BREATHE-2. Eur Respir J. 2004;24(3):353-9.

11. Sitbon O, Sattler C, Bertoletti L, Savale L, Cottin V, Jais X, De Groote P, Chaouat A, Chabannes C, Bergot E, et al. Initial dual oral combination therapy in pulmonary arterial hypertension. Eur Respir J. 2016:47(6):1727-36.

12. van de Veerdonk MC, Huis In TVAE, Marcus JT, Westerhof N, Heymans MW, Bogaard $\mathrm{HJ}$, et al. Upfront combination therapy reduces right ventricular volumes in pulmonary arterial hypertension. Eur Respir J. 2017;49(6): 1700007.

13. Fox BD, Shtraichman O, Langleben D, Shimony A, Kramer MR. Combination therapy for pulmonary arterial hypertension: a systematic review and metaanalysis. Can J Cardiol. 2016;32(12):1520-30.

14. Tamura Y, Kumamaru H, Satoh T, Miyata H, Ogawa A, Tanabe N, Hatano M, Yao A, Abe K, Tsujino I, et al. Effectiveness and outcome of pulmonary arterial hypertension-specific therapy in Japanese patients with pulmonary arterial hypertension. Circ J. 2017;82(1):275-82

15. Galie N, Humbert M, Vachiery JL, Gibbs S, Lang I, Torbicki A, Simonneau G, Peacock A, Vonk Noordegraaf A, Beghetti M, et al. 2015 ESC/ERS guidelines for the diagnosis and treatment of pulmonary hypertension: the joint task force for the diagnosis and treatment of pulmonary hypertension of the European Society of Cardiology (ESC) and the European Respiratory Society (ERS): endorsed by: Association for European Paediatric and Congenital 
Cardiology (AEPC), International Society for Heart and Lung Transplantation (ISHLT). Eur Respir J. 2015;46(4):903-75.

16. Tokunaga N, Ogawa A, Ito H, Matsubara H. Rapid and high-dose titration of epoprostenol improves pulmonary hemodynamics and clinical outcomes in patients with idiopathic and heritable pulmonary arterial hypertension. J Cardiol. 2016;68(6):542-7.

17. Matsubara H, Ogawa A. Treatment of idiopathic/hereditary pulmonary arterial hypertension. J Cardiol. 2014;64(4):243-9.

18. Ogawa A, Ejri K, Matsubara H. Long-term patient survival with idiopathic/ heritable pulmonary arterial hypertension treated at a single center in Japan. Life Sci. 2014;118(2):414-9.

19. Grignola JC. Up-front combination therapy in pulmonary arterial hypertension: from clinical trials to 'real world' observational studies. Int J Cardiol. 2014;173(3):349-50.

\section{Publisher's Note}

Springer Nature remains neutral with regard to jurisdictional claims in published maps and institutional affiliations.

- fast, convenient online submission

- thorough peer review by experienced researchers in your field

- rapid publication on acceptance

- support for research data, including large and complex data types

- gold Open Access which fosters wider collaboration and increased citations

- maximum visibility for your research: over $100 \mathrm{M}$ website views per year

At BMC, research is always in progress. 